\title{
IAMJ
}

INTERNATIONAL

AYURVEDIC

MEDICAL JOURNAL

ISSN: 23205091

Impact Factor: 5.344

\section{DEVELOPMENT \& EVALUATION OF AYURVEDIC CONDITIONER}

\author{
Jain Vatsala ${ }^{1}$, Rao K. Shankar ${ }^{2}$
}

${ }^{1}$ Assistant Professor, Dept. of Rasa Shastra \& Bhaishajya Kalpana, Prabuddh Ayurvedic Medical College Hospital and Research Centre, Lucknow, Uttar Pradesh, India

${ }^{2}$ Professor and HOD Department of Rasshastra and Bhaishajya Kalpana, National Institute of Ayurveda., Jaipur, Rajasthan, India

Corresponding Author: drvatsalajain@gmail.com

https://doi.org/10.46607/iamj2108102020

(Published online: October 2020)

Open Access

(C) International Ayurvedic Medical Journal, India 2020

Article Received: 29/09/2020 - Peer Reviewed: 02/10/2020 - Accepted for Publication: 04/10/2020

(D) Check for updates

\section{ABSTRACT}

Hair Conditioner is one of the cosmetics which is widely used in daily life. In contemporary era, people preferring Ayurvedic cosmetics. Thus, in the present research, herbal active ingredients have been used in maximum possible proportion to enhance the properties of developed Ayurvedic conditioner. For development of Ayurvedic conditioner active part (conditioning agent) Nagakeshar, Musta, Ushira, Hareetaki selected from Kamaratnama and used in the form of decoction (60\%). Other supporting ingredients like Aloevera juice (3\%), Cucumber (2\%), Olive oil $(2 \%)$ selected due to their proved conditioning properties to increase the potency of formulation. To establish the idea conditioner was prepared as an emulsion. The formulation analysed on the basis of various organoleptic and physiochemical parameters like $\mathrm{pH}$, viscosity, rancidity, total microbial count etc. Result showed that conditioner has the standard values needed for a good quality conditioner. It is concluded that formulation has all needed technical as well as aesthetic properties.

Keywords: Ayurvedic conditioner, hair conditioner, cosmetics, emulsion. 


\section{INTRODUCTION}

Hair conditioner is a hair care product used to improve the feel, appearance and manageability of hair. Its main purpose is to reduce friction between strands of hair to allow easier brushing or combing, which might otherwise cause damage to the scalp. Various other benefits are hair repair, strengthening, or a reduction in split-ends. ${ }^{1}$ In contemporary era, people preferring Ayurvedic hair care product like hair conditioner and shampoo. For developing the Ayurvedic conditioner there are many ingredients are available and each ingredient has specific properties \& role. But the main ingredients used in preparation of conditioner are conditioning agent. Thus, in the present work for development of the same active part (conditioning agent) Nagakeshar, Musta, Ushira, Hareetaki selected from Kamaratnama and used in the form of decoction.
Other supporting ingredients like Aloevera, Cucumber, Olive oil selected due to their proved conditioning properties to increase the potency of formulation.

\section{Material and Method}

Raw Material Collection: The plant material Nagkeshar, Musta, Hareetaki and Ushir were procured in the dry form, from the pharmacy of National Institute of Ayurveda, Jaipur. Fresh Aloevera phylloids were collected from herbal garden of National Institute of Ayurveda, Jaipur. Fresh Cucumber fruits and olive oil were collected from local market. Base ingredients were collected from the Drug testing Laboratory (DTL) of Rasa Shastra \& Bhaishajya Kalpana Department, NIA, Jaipur. (Table 1), (Table 2) and (Table 3)

Table 1: Showing Active ingredients of Ayurvedic conditioner

\begin{tabular}{|l|l|l|l|l|}
\hline S.No. & Name & Botanical name & Family & Part used \\
\hline 1. & Hareetaki & Terminalia chebula & Combretaceae & Fruit pericarp \\
\hline 2. & Naagkeshar & Mesua ferrea & Calophyllaceae & Androecium \\
\hline 3. & Nagarmotha & Cyperus rotundus & Cyperaceae & Tuber \\
\hline 4. & Ushir & Vetiveria zizanioides & Graminae & Root \\
\hline
\end{tabular}

Table 2: Showing supporting ingredients of Ayurvedic conditioner

\begin{tabular}{|l|l|l|l|l|}
\hline S.No. & Name & Botanical name & Family & Part used \\
\hline 1. & Aloe vera & Aloe vera & Liliaceae & Phyllode pulp \\
\hline 2. & Cucumber & Cucumis sativus & Cucurbitaceae & Fruit \\
\hline 3. & Olive oil & Olea europaea & Oleaceae & Oil \\
\hline
\end{tabular}

Table 3: Showing composition of Ayurvedic Conditioner

\begin{tabular}{|l|l|l|l|}
\hline S.No. & Ingredients & Action & Concentration $\mathbf{~}(\mathbf{w} / \mathbf{w})$ \\
\hline 1. & Kwath & Active part & 60 \\
\hline 2. & Aloevera juice & Emollient & 3 \\
\hline 3. & Cucumber juice & Emollient & 2 \\
\hline 4. & Olive oil & Emollient & 2 \\
\hline 6. & Silicone & Shining & 4.5 \\
\hline 7. & IPM-Iso Propyl Myristate & Shining & 1.5 \\
\hline 8. & Cyclomethicone & Conditioning agent & 5 \\
\hline 9. & Dimethicone & Conditioning agent & 2 \\
\hline 10. & Cetyl alcohol & Thickening agent & 2 \\
\hline 11. & Cetostearyl alcohol & Thickening agent & 3.5 \\
\hline 12. & Emulsifying wax & Emulsifying agent & 2 \\
\hline 13. & Sodium Lauryl Ethyl Sulphate (SLES) & Surfactant & 5 \\
\hline & & & \\
\hline
\end{tabular}




\begin{tabular}{|l|l|l|l|}
\hline 14. & Glycerine & Humactant & 2 \\
\hline 15. & PG-Propylele Glycol & Humactant & 2 \\
\hline 16. & LLP-Light Liquid Paraffin & Moisturizing & 2 \\
\hline 17. & Preservative & Preservation & 0.5 \\
\hline 18. & Fragrance (Lilac) & Aroma & qs $(\sim 0.5)$ \\
\hline Total & & - & 100 \\
\hline
\end{tabular}

Instruments: Wide mouthed steel vessel, cloth, electrical weighing machine, pounding machine, mixer grinder, 10 no. Sieve, LPG stove, spatula, spoon, glass beakers, measuring cylinder, mental heater.

Packing material: Labelled food grade HDPE plastic boxes of $200 \mathrm{gm}$. capacity.

Following steps were followed during the development of Ayurvedic Conditioner:

1. Primary preparation

2. Preparation of Ayurvedic Conditioner

3. Packaging of prepared formulation

1. Primary preparation: Included following steps

- Preparation of decoction: For the preparation of decoction equally weighed prepared coarse powders of each herbs were taken and mixed well. After that decoction was prepared by adding 16 times of water then reduced to $1 / 4^{\text {th }}$ part and filtered through the double layered cloth.

- Preparation of Aloevera juice: Cleaned Aloevera Phyllodes were cut by knife. Then mucilaginous pulp was separated from the leaves with the help of knife and grind with the electrical stirrer. Juice was filtered by double layered cloth.

- Preparation of Cucumber juice: Cleaned cucumber fruits were cut into small pieces and grinded then juice was filtered by cloth.

2. Development of Ayurvedic Conditioner

Steps followed during development: -

- Preparation of Phase I (Water phase): Phase I was prepared by the addition of Kwatha, Aloevera juice, Cucumber juice, Sodium Lauryl Ether Sulphate, Glycerine and PG were added one by one gradually with continuous stirrer at maintained temperature of $75^{\circ} \mathrm{C}-85^{\circ} \mathrm{C}$ in wide mouthed steel vessel until they get mixed properly. Ingredients quantity taken as mentioned in table 3.

- Preparation of Phase II (Oil phase): Phase II was prepared by Silicone, olive oil, cetyl alcohol, cetosteryl alcohol, IPM , LLP, Emulsifying wax and cyclomethicone added one by one gradually with continuous stirrer at maintained temperature of $75^{\circ} \mathrm{C}-85^{\circ} \mathrm{C}$ in wide mouthed glass beaker until they get mixed properly. Ingredients quantity taken as showed in table 3

- Mixing of phase I \& II: Oil phase was mixed in water phase at reducing temperature $\left(80^{\circ} \mathrm{C}-60^{\circ} \mathrm{C}\right)$ with continuous slow stirring, using electrical stirrer until it becomes lukewarm and thick. After cooling dimethicone (2\%) added in it and mixed well by stirrer. Then Fragrance added in it.

3. Packaging of Ayurvedic Conditioner: Ayurvedic Conditioner was packed in sterilized labelled food grade HDPE plastic boxes of 200 gm capacity.

Analytical evaluation Prepared Ayurvedic Conditioner analysis has been done on the basis of various Organoleptic and physiochemical tests included $\mathrm{pH}$, Total acidity, Total fat content, Rancidity and Total solids etc. Analytical study was carried out at departmental drug testing lab and S.R. labs, Jaipur. Following tests were done.

\section{Organoleptic evaluation}

Physical appearance, colour and odour were noted.

2. pH: The $\mathrm{pH}$ of $10 \%$ conditioner solution in distilled water was determined at room temperature using a $\mathrm{pH}$ meter. ${ }^{2}$

3. Rancidity test: Kreis test method was used to analyse Rancidity. ${ }^{3}$

4. Total acidity evaluation: Estimation of total acidity was done by using phenolphthalein indicator by titration method. ${ }^{4}$ 


\section{Total Fat Content}

For estimation of total fat content, the Weibull- Stoldt method was followed.

\section{Total microbial count ${ }^{[11]}$}

Total microbial count was carried out according to the given reference.

\section{Measurement of Viscosity}

The relative viscosity was measured by using Ostwald-type viscometer. ${ }^{5}$

8. Total solids: A clean dry evaporating dish was weighed and added 4 grams of shampoo to the evaporating dish. The dish and shampoo were weighed. The exact weight of the shampoo was calculated only and put the evaporating dish with shampoo was placed on the hot plate until the liquid portion was evaporated. The weight of the shampoo only (solids) after drying was calculated. ${ }^{6}$

9. Thermal Stability: Physical stability test of the formulation was carried out for two weeks at various temperature conditions like at $45^{\circ} \mathrm{C}$ temperature, room temperature, $4^{\circ} \mathrm{C}$ and $45 \%$ relative humidity in a close container.

Result: Results of the various analytical tests carried out for the Ayurvedic Conditioner are showed in the following tables (Table 4 - 7).

Table 4: Organoleptic parameters of Ayurvedic Conditioner

\begin{tabular}{|l|l|l|}
\hline S.No. & Organoleptic parameters & Ayurvedic Conditioner \\
\hline 1. & Appearance & Viscous paste \\
\hline 2. & Color & Brown \\
\hline 3. & Odour & Pleasant \\
\hline
\end{tabular}

Table 5: Physiochemical parameters

\begin{tabular}{|l|l|l|}
\hline S.No. & Physiochemical parameters & Result \\
\hline 1. & $\mathrm{pH}$ & 5.11 \\
\hline 2. & Rancidity test & Absent \\
\hline 3. & Total acidity & 0.34 \\
\hline 4. & Total Fat Content & $16.34 \%(\mathrm{w} / \mathrm{w})$ \\
\hline 5. & Viscosity & $233.10 \mathrm{~Pa} . \mathrm{s}$ \\
\hline 6. & Total Solids & $20.114 \%$ \\
\hline
\end{tabular}

Table 6: Microbiological analysis of Ayurvedic Conditioner

\begin{tabular}{|l|l|l|l|}
\hline S.No. & Test Parameters & Limits & Ayurvedic Conditioner \\
\hline $\mathbf{1 .}$ & $\begin{array}{l}\text { Microbiological analysis } \\
\text { Total bacterial count }\end{array}$ & $100000 \mathrm{cfu} / \mathrm{g}$ & $140 \mathrm{cfu} / \mathrm{g}$ \\
\hline
\end{tabular}

Table 7: Showing Thermal Stability of Ayurvedic Conditioner

\begin{tabular}{|l|l|l|l|l|}
\hline S.No. & Thermal Stability & At $4^{\circ}$ Temp. & At Room Temp. & At $45^{\circ}$ Temp. \\
\hline 1. & 0 Days & Stable & Stable & Stable \\
\hline 2. & 7 Days & Stable & Stable & Stable \\
\hline 3. & 15 Days & Stable & Stable & Stable \\
\hline
\end{tabular}

\section{DISCUSSION}

In the present formulation good amount of main active part used in the form of decoction to enhance its properties. But sufficient amount of base ingredients was also needed to make a good emulsion.
Conditioners are basically act on shaft of hair and it is important that conditioner must ensure the smoothness, softness, shine of hair shaft and reduce the friction between hair. For this purpose, maintained $\mathbf{p H}$ is an essential factor. The scalp $\mathrm{pH}$ is 5.5 , and the 
hair shaft $\mathrm{pH}$ is 3.67. An alkaline $\mathrm{pH}$ may increase the negative electrical net charge of the hair fibre surface and, therefore, increase the friction between the fibers. ${ }^{7,8}$ As the hair fibre has a $\mathrm{pH}$ of $3.67 \mathrm{It}$ is important that, besides the inclusion of antistatic agents in the conditioner formulas, the formula and ingredients must create a final $\mathrm{pH}$ no higher than 5.5 so not to damage the scalp. ${ }^{9}$ Any product applied on hair that has $\mathrm{pH}$ higher than 3.67 causes an increase in the negativity of the electric network of the hair, that is, an increase of static electricity and the repulsion between strands. The fiber surface bears a net negative charge because of its low isoeletric point. Positively charged ions are attracted to the negatively charged surface, thus helping to overcome the electrical barrier for anions. ${ }^{10}$ The $\mathrm{pH}$ of Ayurvedic Conditioner was 5.11 that was good for hair softness and quality. The deterioration or degradation of fats is termed as 'Rancidity'. There are two basic types or causes of rancidity that cause and/or contribute to the degradation of oils oxidative rancidity and hydrolytic rancidity. During rancidity, fatty acid esters of oils are converted into free fatty acids, by reaction with air, moisture and/or other materials. These fats degrade to the point of becoming either rancid odor and taste. Rancidity testing is an essential component to determine the shelf life of the product When the lipids like fat and oils go rancid, nutritional value of product is compromised and the lipids will take on a rancid taste and odor. To determine the shelf life of the product rancidity testing is an essential component. In the present formulations Ayurvedic Shampoo and Conditioner rancidity was found absent. It means that the product is stable and not pharmaceutically rancid. ${ }^{11}$

Viscosity and rheological properties play important role for liquid and viscous cosmetics. They could influence many of the product attributes, such as shelf-life, its beauty, its transparency, easy removal from its packaging, its expansion and its consistency. ${ }^{12}$ The viscosity property of this formulation showed that this formulation has a proper consistency. Viscosity of Ayurvedic Conditioner was $233.10 \mathrm{P}$ a.s., it shows that the product is viscous paste like and can easily be removable from its packing. Acid contribute to corrosiveness and influence chemical reaction rates, chemical speciation and biological processes. Acidity of water is its quantitative capacity to react with a strong base to a designated $\mathrm{pH}^{13}$ The measured value may vary significantly with the end point $\mathrm{pH}$ used in the determination. Total acidity of Ayurvedic conditioner was 0.34 that was good for formulation.

Total fat content refers to the sum of triglycerides, phospholipids, wax ester, sterols and minor amount of non fatty material. Ayurvedic Conditioner has 16.32\% $\mathrm{w} / \mathrm{w}$ total fat content because it contained olive oil. If the conditioner has too many solids it will be hard to work into the hair or too hard to wash out. The present formulation contains right amount of total solid, so it was easily removable and maintain hair texture.

Microbiological assay of the formulation has not shown any contamination with microbes and hence completely safe and have been prepared under Good Manufacturing Practices. The formulation was found chemically and physically stable and acceptable on the basis of various test and thermal stability test.

\section{CONCLUSION}

As per the evaluation of organoleptic and physiochemical parameters of formulation it can be expected that conditioner has the standard values needed for a good quality conditioner such as colour, soothing fragrance, smoothness and shine. Finally, it is recommended that developing conditioner with high amount of herbal part as industrial purpose should be considered. But clinical research is needed for this purpose.

\section{REFERENCES}

1. https://en.wikipedia.org/wiki/Hair_conditioner

2. Imran Patel, Adnya Talathi. Use of traditional herbs for the formulation of shampoo and their comparative analysis. J Pharm Pharm Sci 2016; 8(3): 28-32

3. Anonymous, The Ayurvedic Pharmacopoeia of India, Part I, Vol-VI, appendix 2.2.22, I ed., Government of India, Ministry of health and Family welfare, Department of Health, New Delhi 2008; p 335

4. Anonymous, The Ayurvedic Pharmacopoeia of India, Part I, Vol-VI, appendix 2.2.22, I ed., Government of 
India, Ministry of health and Family welfare, Department of Health, New Delhi 2008; p 250

5. Anonymous, The Ayurvedic Pharmacopoeia of India, Part I, Vol-VI, appendix 3.4, I ed., Government of India, Ministry of health and Family welfare, Department of Health, New Delhi 2008; p 297

6. Ashok Kumar, Rakesh Roshan Mali. Evaluation of prepared Shampoo formulation and to compare formulated Shampoo with marketed Shampoos. International Journal of Pharmaceutical Sciences Review and Research, 2010; 3(1): 120-6.

7. Sinclair RD. Healthy hair: What is it? J Investig Dermatol Symp Proc. 2007; 12:2-5.

8. Robbins CR, Crawford RJ. Cuticle damage and the tensile properties of human hair. J Soc Cosmet Chem. 1991; 42:59-67.

9. Maria Fernanda Reis Gavazzoni Dias, Andréia Munck de Almeida, Patricia Makino Rezende Cecato, Andre Ricardo Adriano, and Janine Pichler, The Shampoo pH can Affect the Hair: Myth or Reality?, Int J Trichology 2014 Jul-Sep; 6(3): 95-99.

10. Harris DC. 6th ed. Rio de Janeiro: LTC; 2005. Medida do $\mathrm{pH}$ com um eletrodo de vidro. Análise Química Quantitativa; pp. 312-9.

11. Guest post, Test For Rancidity Of Fats - Kreis Test, Discover food tech.

12. Al-Achi et al., 2007

13. Dr. Arun Kumar, Laboratory experiment 2: Acidity and Alkalinity, Indian institute of technology Delhi.

\section{Source of Support: Nil \\ Conflict of Interest: None Declared}

How to cite this URL: Jain Vatsala \& Rao K. Shankar: Development \& Evaluation of Ayurvedic Conditioner. International Ayurvedic Medical Journal \{online\} 2020 \{cited October, 2020\} Available from: http://www.iamj.in/posts/images/upload/4710 4715.pdf 